is an interesting fact that the bead waters of tributaries of the Columbia, the Colorado, the Missouri, and the Yellow Stone rivers rise within a short distance of each other in this mysterious region; which, in addition, is characterised by the extraordinary development of hot springs, spouting geysers, mud volcanoes, extensive beds of sulphur, gypsum, the silicates, \&c. The party, as at present organised, embraces thirty-two persons, including specialists in all branches of science, and accompanied by several artists, who take advantage of Dr. Hayden's protection to visit the interesting region referred to. The party carries materials for a boat, which is to be launched on the Yellow Stone Lake, and used in a thorough hydrographical and topographical survey of it. As the expedition will probably remain in that vicinity during the summer, we may hope for a comolete solution of all the remaining questions in regard to its physical features and natural history. A competent photographer with the expedition expects to make instantaneous views of the spouting geysers, so as to enable those who cannot visit the locality to have a correct idea of their character. A company of cavalry will escort the expedition into the Yellow Stone Lake region, although no trouble from the Indians is anticipated. In the course of the journey from Ogden to Fort Ellis it is proposed to malie an accurate map of a belt fifty miles wide, so as to furnish a basis for reference in subsequent explorations. In the monthly report of the Department of Agriculture for March and April of the present year, we find a valuable pape upon the cultivation of the Cinchona in Jamaica, by Dr. C. C Parry, the botanist of the Department, who accompanied the San Domingo Investigating Comnittee, and in returning spent some time in Jamaica. As the general result of his inquiries in regard to the cultivation of this plant, and the possibility of introducing it into any portion of the United States, he states, first, that the peculiar conditions of soil and climate suitable for the growth of the best varieties of cinchona plants cannot be found within the present limits of the United States, where no stitable elevations possessing an equable, moist, cool climate, free from frost, can be met with; second, that the island of San Domingo, located within the tropics, and traversed by extensive mountain ranges attaining elevations of over 6000 feet above the sea, presents a larger scope of country especially adapted to the growth of cinchonas than any other insular region in the western hemisphere; third, that the existence of successful cinchona plantations in Jamaica within two days' sail from San Domingo, would afford the material for stocking new plantations in the latter island at the least possible expense of time and labour.-.-In a recent communication to the Academy of Natural Sciences of Philadelphia, by Prof. Leidy, attention was invited to certain teeth of fossil mammals, forwarded to him for examination by Prof. Whitney. One of these was a fragment belonging to the Mastodon americanus, obtained from a depth of eighty feet beneath the basalic Iava of Table Mountain, Tuolumne County, California, where it was found associated with the remains of human art. There was also a molar of a large fossil horse, found sixteen feet below the surface on Gordon Gulch. Two other teeth, somewhat similar in character, were determined as belonging to the species of Protohifpus. In other specimens Dr. Leidy found evidences of the existence of a gigantic animal of the camel tribe, allied to the llama.

\section{CORRESPONDENCE OF NORTHERN AND SOUTHERN AURORAE}

I TAKE the liberty of sending you a paper containing corresponding observations of Aurora Borealis and Australis, with the request to insert them in your valuable journal.

Corresponding Observations of Aurora Polaris, made in the Northern and Southern Hemispheres.

In the years 1859-65 I kept up a correspondence with the active director of the Flagstaff Observatory at Melbourne, (Australia), Mr. George Neumayer, in order to make observations concerning the contemporaneous appearance of aurora polaris in the northern and southern hemispheres.*

* See Results of the magnetical, nsutical, and meteorological observations made at the Flag itaff Observatory, Me bourne, and at various stations in the colony of Viccoria, Mesb urne, r860. Heis, "Wochenschrift für Astronomie und Meteorologie," $1859, x 860, x 86 \mathrm{r}, 1863,1865$.
Some years since, when Dr. Neumayer returned to his native country, this correspondence was interrupted. But the numerous appearances of aurora borealis which occurred last year, induced me to recommence this correspondence with the present director of the same establishment, Mr. C. Moerlin. Sending him a list of all the appearances of aurora borealis and magnetical disturbances in the year 1870 known to me, I begged him to favour me with the corresponding observations viewed by him. I subjoin the answer of Mr. Moerlin.

I received your letter of December 2, 1870 , and in reply shall be most happy to comply with your request, of informing you periadically of the occurrence of the aurora australis, and of magnetic disturbances observed here.

To this end I have made out a list, which is enclosed, of auroræ observed since January I, 1870, containing the dates and times (Melbourne mean time) of their occurrence, from which it appears that at most of the dates you mention in your letter, as having observed the aurora borealis, the aurora australis has been observed here. The greatest magnetic disturbances occurred on April 5 and October 25 ; on the latter day the disturbances continued during two days; the minimum of easterly declination occurred about $5 \mathrm{~A} . \mathrm{M}$. on the $26 \mathrm{th}$, and the maximum about 6 A.M. on the same day, the range being $5 \mathrm{I}^{\prime}$ of arc, with corresponding dis: urbances in the other two elements. Unfortunately the sky was completely overcast during the night, with a slight break only at midnight, when the display was very beautiful, but visibie only for a few minutes; but during the evening of the $25^{\text {th }}$ an intense, but ever varying, luminosity only of the whole southern sky was the sole indication of aurora.

I would remark that at all the dates on which aurorae were observed, magnetic disturbances invariably took place of a greater or less extent ; but disturbances occurred also at other times, of the very same nature as took place generally during aurora displays, on which, however, no auroræ were observed. These dates I give you enclosed also, separately, as these may be of interest to you in connection with the possible occurrences of the aurora borealis on one or the other of those dates.

I shall continue from this date to send you periodical notice of the occurrence of the aurora australis and magnetic disturbances at Melbourne, and shall be happy to furnish any information respecting physical phenomena, which you may desire, and I may be able to give.

Melbourne Observatory, $\mathrm{Feb} .7$

Date and time of occurrence of the Aurora Australis observed at Melbourne during the period from January I, 1870 , to February $2 \mathrm{I}, \mathrm{I} 87 \mathrm{I}$, during which, at the same time, great disturbances in the magnetic elements generally took place.
LAT. $37^{\circ} 49^{\prime} 53^{\prime} 5^{\prime \prime} \mathrm{S}$. LONG. $9^{\text {h }} 39^{\mathrm{m}} 54^{\circ} 8^{\mathrm{s}} \mathrm{E}$.

1870 , January 8.-During the evening the aurora was seen at Adelaide, South Australia, as reported by $\mathrm{Mr}$. Food, Superintendent of Electric Telegraph.

February 1.-A fine display between 8 and IO P.M.; shortly after nine some magnificent streamers.

April 5.-Became visible shortly after $7^{\text {h }}$ P.M., and lasted all through the evening and night. The display at times was most brilliant, particularly at $\mathrm{IO}^{\mathrm{h}} 3 \mathrm{O}^{\mathrm{m}}$ P.M., and again at $12^{\mathrm{h}} 3 \mathrm{O}^{\mathrm{m}}$. Slight disturbances in the magnetic elements occurred during the afternoon, which increased shorily before $7^{\mathrm{h}}$ P.M. At $10^{\mathrm{h}} 45^{\mathrm{m}}$ P.M. a rapid decrease of easterly declination and increase of horizontal force took place, which lasted until a few minutes before I I $^{\mathrm{h}}$ P.M., when both elements as rapidly returned to their former state. Comparatively slight disturbances until $12^{\mathrm{h}} 30^{\mathrm{m}}$, when a similar movement to the above mentioned took place, but to a smaller extent. The minimum of easterly declination took place a few minutes before $\mathrm{I}^{\mathrm{h}}$ P.M., and the maximum at 10 minutes before $6^{\mathrm{h}}$ A.M. on the 6 th, and the range of the disturbance amounted to about $54^{\prime}$ of arc, while the range in the horizontal force was 0.06273 of the absolute (English) unit $=0^{\circ} 02892$ Continental unit.

May 20.-Faint display, most distinct at $10^{\text {h }} 30^{\text {m }}$ P.M.

August 22.-At $6^{\mathrm{h}} 40^{\mathrm{m}}$ P.M. some fine streamers visible, but not for long.

September 21.--Visible from about $6^{\text {h }}$ to $8^{\text {h }}$ P.M. , but not 
very brilliant ; 24 , visible from shortly before $9^{\mathrm{h}}$ P.M.; the finest display took place $\mathrm{I}^{\mathrm{h}}$ P.M.; 25 , traces visible during evening in S.S.E.; 30 , traces visible during evening, S.E.

October $2 \mathrm{I}$. - Visible during the evening, at $1 \mathrm{O}^{\mathrm{h}} 3 \mathrm{O}^{\mathrm{m}}$ P.M. some fine streamers $30^{\circ}$ and $40^{\circ}$ high; 25 , visible at times during the evening, though completely overcast, as a luminous sheet, extending from S.W. to S.E.; 26 , shortly after midnight a beautiful display, though cloudy.

November 9.-Visible shortly after midnight until early morning, again during the whole evening; fine red streamers visible through bright moonlight; I 5 , auroral light visible during the evening, but no streamers; 17 , visible at $9^{\text {h }}$ $30^{m}$ P M., for a short time; 18 , visible all through the evening; 19 , visible all through the evening; at $9^{\text {h }} 20^{m}$ P.M. very fine streamers; 20 , visiblefrom $\mathrm{II}^{\mathrm{h}} \mathrm{P} \mathrm{M}$.; at 10 minutes past midnight, a fine display, with streamers extending from S.E. to S.W. At $4^{\mathrm{h}}$ A.M. on the 2 Ist the whole extent of the southern sky, from the horizon upwards, was illuminated by a reddish light, terminating in something resembling a corona, but no streamers at all were visible; a thunderstorm occurred towards daylight, and the whole appearance vanished instantaneously at $4^{\mathrm{h}} 4 \mathrm{O}^{\mathrm{m}} \mathrm{A} . \mathrm{M}$, when a terrific thunderclap occurred; 23 , visible between $I^{\text {li }}$ P.M. and midnight; 24 , traces visible all through the evening; 25 , traces visible all through the evening; 29 , visible from $8^{\mathrm{h}} 3 \mathrm{O}^{\mathrm{m}}$ to $10^{\mathrm{h}}$ P.M., but not brilliant.

December 10-Faint streamers visible all through the evening; 16 , visible all through the evening, at $10^{12}$ P.M. very fine streamers, and at intervals, up to $2^{\mathrm{h}} \mathrm{A}, \mathrm{M}$. on the 17 th, a very fine display; 17 , visible during the evening, some fine streamers at $9^{\text {in }}$ P.M.

I 871 , January 3.-Visible during the evening; 13, visible after $I^{\text {I }}$ P.M, no streamers, but strong reddish light in S.S.W.; 15 , at midnight, faintly visible ; 20 , visible during evening, but only faint; $2 r$, visible during evening, but only faint.

February 12 , visible for a short time at $9^{\text {h }}$ P.M.

List of dates when great disturbances in the magnetic elements took place, of the same nature as during auroral displays, but when no auroras were visible, or at least observed :

1870: January 3, 4 ; February IO, II ; March 20, 21; April 22, 23, 28; May 16; June 13, I4, 16, 17 ; July 5,28 ; August 3, 7, 19, 20, 21, 23; September 4, 5, 6, $7,8,16,18,26,27$; October 1, 15, 24; November 10, 22, 27 ; December 5, 6, 7, 9, I I, 15, 22, 23, 25, 27. 187 1 : January $5,6,10,27,28,30$; February $4,5,9,13,14,15$.

We add to the above-mentioned auroræ australes and magnetical disturbances observed in Melbourne the following ones observed in our own hemisphere :

I 870, January.-To the aurora on January 8, at Melbourne, corresponds the aurora borealis on 8 th at Oxford, Liverpool, Cockermouth, and North Shields. To the magnetic disturbances on January 3 and 4 correspond the disturbances observed on the same days at Rome; on January 3 auroræ boreales were observed in Piedmont and in France ; also in England at Guernsey, Worthing, Royston, Norwich, Boston, Eccles, and Culloden. Aurora borealis visible on the 4th in England at Wisbech.

February.-To the aurora australis visible on February I, from 8 to $\mathrm{IO}^{\mathrm{h}}$, at Melbourne, correspond the aurora borealis seen at many places of the Europe on the same day, at Münster, Munich, Ruhrort, Nevtomysl, Peckeloh, Lennep, at Upsala $\left(5^{\text {h }} 5 \mathrm{O}^{\mathrm{m}}\right.$ to $\left.\mathrm{I} 3^{\mathrm{h}}\right)$, also at Coeslin, Petersburg, Königsberg, Paris, London, Calais, Cracow, Stockholm, and in England at Eastbourne, Royston, Little Wratting, Norwich, Wisbech, Boston, North Shields, and Culloden. To the magnetic disturbances on IIth at Melbourne correspond the aurora borealis observed on the same day at Upsala, and in England at Taunton, Wilton, Streatley, Cardington, York, Hawsker, North Shields.

March.-To the magnetic disturbances at Melbourne on the 2Ist correspond the magnetic disturbances at Rome on the 22nd and the aurora borealis in England at Little Wratting, Stonyhurst, and York.

April.-To the aurora australis on April 5, at Melbourne, correspond the aurora australis observed at many places of Europe on the same day, at Münster, Peckeloh, Lennep, Bonn, Linzig, Dülken, Brunswick, Niederorschel, Stettin, Kurnik, Munich, Feldkirch, Wolgast, Berlin, France and Italy, Paris, Austria, Athens, at Upsala, Petersburg, Riga, Pulbus, and Stockholm. To the magnetic disturbance on April 23 correspond the magnetic disturbances at Rome, and the aurora borealis at Papenburg on the same day.

May.-To the aurora australis on the 2oth at Melbourne corresponds the very fine aurora borealis at Münster, which also was seen on the same day at Mannheim, Paris, and London, and the great magnetic disturbances visible in Rome and Munich.

June.-To the magnetic disturbances in Melbourne on the $13, I 4,16,17$ correspond the magnetic disturbances at Rome on the same days. (Bulletino Meteorologico dell' Osservatorio del Collegio Romano, No. 7, vol x.)

July,-To the magnetic disturbances on July 8 and 28 at Melbourne correspond the disturbances at Rome on the same days.

August.- To the aurora australis on the 22nd at Melbourne corresponds the aurora borealis on the 2 Ist at Volpeglino near Tortona in Italy. To the magnetic disturbances in Melbourne on the 3, 7, 19, 20, 21, 23 correspond the contemporary disturbances of the magnetic instruments at Rome. With the magnetic disturbances on the 7 th the aurora borealis at Upsala coincides. With the disturbance on the I 9 th the aurora borealis at Muinster and at Carthaus near Dülmen. With the disturbances on the 2oth the aurora borealis at Münster, Groeningen, Peckeloh, Oesel, Leipzig, and Upsala. To the magnetic disturbance on the 23 rd corresponds the aurora borealis at Glasgow.

September.-To the aurora on the 25th in Melbourne corresponds the aurora borealis at Carthaus, Danzig, Peckeloh, Weisenheim, also at Arnsburg, Oesel in Schleswig, Lichtenberg, Hamburg, Upsala. To the aurora australis on the 26th at Melbourne corresponds the aurora borealis at Lichtenberg, Weisenheim, Upsala, Glasgow. To the aurora on the 3 oth at Melbourne corresponds the aurora borealis on the same day at Upsala and Lichtenberg. To the aurora australis on the 2 Ist at Melbourne correspond the contemporary aurora borealis at Upsala, Schleswig, Arnsburg, Lichtenberg, Hamburg, Norburg, Alsen, and the magnetic disturbance at Rome. To the aurora on the 24 th at Melbourne corresponds the contemporary aurora borealis at Carthaus near Duilmen, Niederorschel, Groeningen, Danzig, Wolgast, Peckeloh, Weisenheim, Norburg, Alsen, Eger, Prague, Oderberg by the Inn, Kremsmünster, Moncalieri, Vienna, Stockholm, Hawkhurst, London. On the same day great disturbances of the magnetic instruments were observed at Rome and at Kremsmünster.

October.-To the aurora australis on the 2Ist at Melbourne corresponds the aurora borealis on the same day in England, and on the former day in Westphalia and England. To the aurora australis on the 25 th at Melbourne corresponds the brilliant aurora borealis which was seen at many places in Germany, England, Russia, Sweden, Italy, Greece, and Turkey on the same day. To the aurora on the 26 th at Melbourne corresponds the aurora borealis on the same day in Hamburg, Lichtenberg, Keitum, Athens, and in England. To the magnetic disturbances on the Ist at Melbourne corresponds the aurora borealis at Peckeloh, Upsala, and in England, and the magnetic disturbances on the same day. To the magnetic disturbances on the I 5 that Melbourne correspond the contemporarymag-

* Bulletino Meteorologico dell' Osservatorio del Collegio Cario Alberto in Moncalieri. 
netic disturbances in Rome, and the aurora borealis at $U$ psala. Tothe magnetic disturbance on the 24 th at Melbourne correspond the great magnetic disturbances at Rome, and the very fine auroræ boreales on the same day in Germany, Russia, England, Turkey, Greece, and Sicily.

November.-The aurora australis of November 9 at Melbourne, lasting from midnight till the morning twilight, corresponds to an hour to the aurora borealis which was seen at clear full moon on the evening of the 8 th in Schleswig, and to the magnetic disturbances at Rome on the 8th and 9th. To the aurora australes on the 15 th, I7th, and I8th at Melbourne correspond the auroræ boreales on the 14 th, I 7 th, and I8th in England. To the great aurora australis on the rgth at Melbourne corresponds the contemporary aurora borealis at Münster, Niederorschel, Peckeloh, Schleswig, also at Upsala and in England. 'To the aurora on the 23rd in Melbourne corresponds the aurora borealis in England of the $22 \mathrm{nd}$ and $23 \mathrm{rd}$. To the aurora australis of the 24th corresponds the aurora borealis at Upsala of the 24th and in England. The magnetic disturbances at Rome on the I9th, 20th, 23rd 24 th, 25 th, and 29 th coincide with the aurora australis, on the same days, and the magnetic disturbances at Rome on the 10 th, 22nd, and 27 th, with the disturbances at Melbourne on the same days.* Besides the aurora borealis on the 22nd in England, and on the 27 th in Briinn coincide with the contemporary magnetic disturbances at Melbourne.

December.-To the aurora australis on the 6 th and $I 7$ th at Melbourne corresponds the aurora borealis at Peckeloh, Keitum, and in England. To the aurora on the 17 th at Melbourne corresponds the contemporary aurora borealis at $M$ ünster, Schleswig, Breslau, Keitum, and in England. The magnetic disturbance on the 22nd at Melbourne coincides with the aurora borealis on the 22nd in Schleswig.

January 1871 . - To the aurora australis on the $3 \mathrm{rd}$ and I $3_{\text {th }}$ at Melbourne correspond the magnetic disturbances at Rome on the same day, and to the aurora australis of the I $3^{\text {th }}$ corresponds the aurora borealis on the same day at Münster, Breslau, Cologne, Schleswig. To the aurora on the I5th at Melbourne corresponds the aurora borealis at Breslau and Schleswig on the 15 th. To the aurora on the 2oth at Melbourne corresponds the aurora borealis on the 19th at Thurso.

February.-To the aurora australis on the I2th at Melbourne corresponds the aurora borealis on the rath at Muinster and Niederorschel, Peckeloh, Wolgart, Moncalieri, Coeslin, Breslau, the pharos of the Weser, on the west coast of England, Eger, Datschitz, Florence, Rome, Volpeglino, and the aurora borealis on the 13th at 3 A.M. at Rome. The magnetic disturbances on the 4th at Melbourne correspond to the magnetic disturbances at Rome on the same day. To the magnetic disturbances on the 5 th at Melbourne corresponds the aurora borealis at Breslau. To the magnetic disturbances on the $9^{\text {th }}$ at Melbourne corresponds the aurora borealis at Cleve and Thurso.

Münster, Westphalia, June 30

EDWARD HEIS

\section{SOCIETIES AND ACADEMIES}

\section{LONDON}

Entomological Society, July 3.-A. R. Wallace, president, in the chair. Prof. Westwood exhibited the minute-book of proceedings of an Entomological Society existing in London in I 780 , but which appeared to have been dissolved after about a year. The members seemed to have consisted of Messrs. Drury, Honey, Swift, Francillon, Jones, and Bentley; the meetings being held weekly.-Mr. S. Stevens exhibited a collection of * Bulletino Meteorologico del Collegia Romano, delY Osservatorio di Palermo edel Collegio Carlo Alberto a Moncalieri.
Coleoptera recently made in Ireland, the most interesting species being Chlcmizus holosericeus from near Killaloe. Mr. Champion exhibited an example of Emus hirtus recently captured by him in the New Forest ; also rare British Hemiptera. Mr. Blackmore exhibited a collection of insects of all ordersfrom Tangiers; locusts were extremely destructive there, and on the shore the pedestrian is often up to his ankles in the dead and dying accumulations of these insects. $-M$ r. Dunning read a letter from the Rev. Mr. Wayne, of Much Wenlock, calling attention to the damage done to his strawberries in consequence of a Myriopod effecting an entrance into the interior of the ripe fruit; also complaining that his young carrots were destroyed by a dipterous larva, probably that of Psila rosce, which bored into the root.-Mr. Druce exhibited a collection of rare Diurnal Lepidoptera, including species of Papilio, Euryades, Heliconia, Eresia, Catagramma, Agrias, Paphia, \&c.Mr. Stainton exhibited an example of Botys fuscalis captured by the Rev. R. P. Murray in the Isle of Man, to the head of which a portion of the puparium still adhered; the insect was flying briskly when taken, notwithstanding that it must have been nearly blind. Mr. Albert Müller exhibited a leaf from a vine growing at Basle showing the damage done by Phytoptus vitis.-Mr. Riley, State Entomologist for Missouri, exhibited a collection of American insects with their transformations.-Prof. Westwood read a paper on new species of exotic Papilionidce. Mr. S. S. Saunders read a monograph of the Strepsiptera, describing twenty-one species; he considered the group as undoubtedly pertaining to the Coleoptera, in the vicinity of Rhipiphorus. Mr. C. O. Waterhouse read a memoir on some species of Can. tharis. The Baron de Selys Longchamps communicated a statistical sketch of the Odonata; the number of species of dragon flies now known he estimated at $I, 344$.

Society of Biblical Archæology, July 4.-Samuel Birch, LL.D., F.S.A., in the chair. The Rev. F. K. Cheyne, M.A., was duly elected a member of the society. The Rev. B. T. Lowne, M.R.C.S., read a paper "On the Flora of Palestine." $\mathrm{He}$ considered that it comprised eight distinct elements, four of the dominant existing floras of Southern Europe, Russian Asia, North Africa, and that of Arabia and North Western India. Each of these floras was stated to occupy a distinct region of the rountry. Interspersed with these are found numerous examples of plants belonging to palæarctic Europe, constituting its fifth element. The Arctic flora of Hermon and Lebanon constitutes the sixth. Mr. Lowne thought further that the cedars of the Lebanon, and the papyrus of the Jordan lakes were the remnants of two ancient and almost extinct floras belonging to two distinct geological periods. - James Collins read a paper "On the Gums, Perfumes, and Resins mentioned in the Bible," particularly pointing out the fact that few of them were indigenous to Palestine, and that many have been wrongly named by the Greek and later botanists. In the course of his observations Mr. Collins detailed the characteristic differences between the true and false Balm of Gilead, ladanum, sandal wood, \&c., and the greater or less efficacy of their medicinal properties. Mr. Lowne and $\mathrm{Mr}$. Collins brought for exhibition a large number of mounted specimens, and a complete collection of gums, perfumes, \&c., to illustrate their respective papers.

\section{PARIS}

Académie des Sciences, June 28.-M. Claude Bernard in the chair. M. Robin presented a new edition of his great worls on the Microscope-M. Elie de Beaumont presented a most valuable book by $M$. Rivat, who died recently, and who was one of the chief engineers in the mining service, containing a new method of extracting silver from sulphuric ores, with the assistance of super-heated steam. The quantity of steam required was originally very great, and is now reduced to $\frac{1}{50}$ th of what it was when the first experiments were tried. 'I his process of quantitative analysis is largely used in the Laboratory of the Ecole des Mines, at Paris. - Father Secchi sent a memoir on a sup. posed relation between protuberances, sun-spots, and "faculæ," as discovered by him.-M. Struve and others sent a letter on be half of the German astronomers, who will meet at Vienna, and asking for the presence of French astronomers. Some instru. ments destroyed by the Communists were intended for that meeting. - M. Delaunay has circulated amongst the members small notice relating to an intended meteorological atlas 0 France, and presented the volume of meteorological observation: made at the National Observatory, which he calls the "Obser vatory of Paris." M. Charles Sainte-Claire Deville rose im mediately in order to present the French Academy with thi 